特集：イヌの行動学・心理学

\title{
イヌの社会性解明へ向けた発達行動学的アプローチ
}

\author{
麻布大学獣医学部 茂木一孝・永澤美保・菊水健史
}

\section{A developmental approach to dog's sociality}

\author{
Kazutaka Mogi, Miho Nagasawa and Takefumi Kikusui \\ School of Veterinary Medicine, Azabu University
}

\begin{abstract}
A special relationship between human and $\operatorname{dog}$ is considered to be established by dog's characteristic social skill and cognitive ability, based on adequate emotional and affiliative behavior. It has been emphasized that puppy's experience in its developing period is prerequisite for dog's socialization to human. On the other hand, it is also indicated that if maternal environment is deprived, it would cause various behavioral problems of impairing dog's sociality in adulthood, such as anxiety, fear-related behavior, or aggression toward human. These suggest that maternal environment in dogs could have a large impact on the human-dog relationship. In various mammalian species including human, the quality of mother-infant relationships has been shown to affect neurobehavioral development related to sociality. However, there are few studies in dogs. This article discusses how dog's sociality can be influenced by maternal environment in each developmental stage of puppy, and underlying predictable mechanisms for it. The developmental approach to dog's sociality will be beneficial for better understanding of a special relationship between human and dog.
\end{abstract}

Key words : dog, maternal environment, sociality

\section{1. イヌの社会性研究の現状}

イヌ Canis familiaris は考古学的に家畜化され た最古の動物であることが示唆されており (Serpell, 1995), 現在の人間社会におけるその在り様をみても, ヒトHomo sapiensにもっとも身近でヒトからもっ とも愛情を注がれる伴侣動物としてのニッチを獲得 していることは疑いようもない事実である。イヌは 当然のように人間社会に溶け込んでいるが，イヌ以 外にもどれだけ多くの種類の動物が地球上に生息し ているのかを考えれば，このヒトーイヌ間の親和性 は特異的ともいえるだろう。イヌが人間社会にこれ だけ溶け込むことを可能にしている理由としては, イヌがヒトとのコミュニケーションを可能にする高 度な認知能力と社会技能を有しているからであるこ とが, 過去10年ほどのあいだに盛んになったオオカ

Published online in J-STAGE: July 10, 2009 doi: 10.2502/janip.59.1.10
ミCanis lupusなどとの比較認知学的研究から示 唆されてきている。たとえば，ヒトの赤ちゃんの母 親との分離および再会時の反応パターンを調べるス トレンジシチュエーションテストをイヌに応用した 実験では，イヌは飼い主と他人に対して異なる反応 パターンを示すが (Topál, Miklósi, Csányi, \& Dóka, 1998), ヒトが飼い育てたオオカミに同じテ ストを実施すると，飼い主と他人に同じ反応パター ンを示すことが報告されている (Topál, Gácsi, Miklósi, Virányi, Kubinyi, \& Csányi, 2005)。 つまり，イヌは飼い主と他人が異なるということを 認知して飼い主に特異的な反応を示すが，少なくと もこのテスト条件下ではオオカミは飼い主を認知で きない，あるいは飼い主に特異的な反応を示さない ことが推測される。また，イヌにはヒトが指差した り見つめたりすることで対象物の入った容器を正し く選択する能力のあることが明らかとなっている (Hare, Brown, Williamson, \& Tomasello, 
2002 ; Virányi, Gácsi, Kubinyi, Topál, Belényi, Ujfalussy \& Miklósi, 2008)。しかし，異論はあ るものの (Udell, Dorey \& Wynne, 2008), オオ カミはこのようなヒトの指差しに反応できないこと が報告されている（Hare, Brown, Williamson, et al., 2002 ; Virányi, Gácsi, Kubinyi, et al., 2008)。さらに，ヒトが飼い育てたオオカミとイヌ の両方に同じ課題学習を習得させた後, その課題を 人為的に達成できない状況にした場合，イヌはヒト に振り返ってヒトと対象物に交互に視線を投げかけ るが，オオカミはそのような反応を示さないといっ たことも報告されている (Miklósi, Kubinyi, Topál, Gácsi, Virányi, \& Csányi, 2003)。これらの研究 から，イヌはヒトと指差しや視線を介してノンバー バルな異種間コミュニケーションを可能にする高度 な社会技能を有していることが考えられる。このよ らに, イヌとオオカミとの比較認知学的研究からは, 少なくとも姿形が類似しているオオカミではなく, なぜイヌのほうがこれだけ人間社会に溶け込んでい るのか，その一端が推測される。

イヌはどのようにして高度な認知能力や社会技能 を獲得したのだろらか? その答えを示唆する興味深 い実験にイヌ科の野生動物であるキッネVulpes vulpes の家畜化実験がある。ロシアで実施された この実験では，ヒトに対して恐怖反応や攻撃行動を 示さないキツネを育種選抜し，キツネを家畜化する ことに成功した。興味深いことにこの家畜化キツネ は，育種選抜をしなかったキツネとは異なり，ヒト の指差しをイヌと同様に理解することが報告されて いる (Hare, Plyusnina, Ignacio, Schepina, Stepika, Wrangham, \& Trut, 2005)。Hare \& Tomasello（2005） はこのようなことから，イヌ で認められる高度な社会技能はヒトに対する恐怖反 応や攻撃行動が低いことを指標に選抜した家畜化の 過程で獲得されたものではないかという仮説を提唱 している。また，家畜化されていないキツネと比較 して, この家畜化キツネでは攻撃行動や不安に関連 するセロトニン神経系が変化していることが確認さ れている (Popova, Voitenko, Kulikov, \& Avgustinovich, 1991)。さらに，家畜化キッネでは下 垂体から分泌される副腎皮質刺激ホルモンおよび副 腎皮質から分泌されるグルココルチコイド (GC) の血中の基礎的なレベルや，ストレスに対する GC 分泌反応が低いこと, 寸なわち視床下部一下垂体一 副腎軸（H-P-A 軸）の活性低下も明らかになって おり (Oskina, 1996), Hare \& Tomasello (2005) はこのような $\mathrm{H}-\mathrm{P}-\mathrm{A}$ 軸の活性低下が恐怖反応や攻 撃行動を抑える一因となっているのではないかとい うことを推測している。イヌの有する高度な社会技
能がどのようなメカニズムによって発現されるかは 未だ推測の域をでないが，家畜化キッネの興味深い 実験からは，そのメカニズムが恐怖反応，攻撃行動 発現に関与する神経機構や, H-P-A 軸の調節機構 と関連のある可能性は充分に考えられる。

近年, 神経科学領域では恐怖反応や攻撃行動など に関与する神経機構に加えて, 社会行動や社会認知 に関与する分子が同定され始めたことにより，他個 体への親和行動といったこれまで曖昧に捉えられて いた社会行動や社会認知に重要な神経機構を探る試 みが活発に行なわれている。ヒトーイヌ間の特異的 な親和性についてもそのような視点から説明しょう とする萌芽的な試みが徐々にではあるが始められて いる。たとえば Odendaal \& Meintjes（2003）は ヒトとイヌが交流する前後の両者の血中ホルモンレ ベルを比較し，ヒトとイヌのどちらにおいても相互 の交流によってオキシトシン (OT) 分泌が促進さ れることを初狂明らかにした。 OT は脳内視床下 部のニューロンが産生するペプチドホルモンである が，ラットRattus norvegicus では脳室内への投与 によって毛づくろい行動, 他個体一の接触, 母性行 動などの社会行動が増加し (Pedersen, Caldwell, Drago, Noonan, Peterson, Hood, \& Prange, 1988 ; Witt, Winslow, \& Insel, 1992), 脳脊䯣液 中の OT 濃度も社会行動と正の相関を示すことが 報告されている (Haller, Makara, Barna, Kovacs, Nagy, \& Vecsernyes, 1996)。さらに遺伝子工学に よって OT を欠損させたマウス Mus musculus で は社会認知機能が障害されることも明らかとなって いる (Ferguson, Young, Hearn, Matzuk, Insel, \& Winslow, 2000 ; Winslow \& Insel, 2002)。ま た，生物学的に完全な一夫一婦制をとるプレーリー ハタネズミMicrotus ochrogasterにおいては, OT や OT に類似するぺプチドホルモンであるバソプ レッシンが一夫一婦制の形成維持に必須なホルモン であることも明らかとなっている (Young, Lim, Gingrich, \& Insel, 2001; Young \& Wang, 2004)。ヒトにおいても分婏後の母親の血中 OTレ ベルと母親が子供に示す母性行動に正の相関が認め られることや(Feldman, Weller, ZagoorySharon, \& Levine, 2007), 自閉症患者においては 血中 OTレベルが低く (Green, Fein, Modahl, Feinstein, Waterhouse, \& Morris, 2001 ), OT 受容体をコードする遺伝子の変異と自閉症発生率と に相関があるといった報告もあることから（Wu， Jia, Ruan, Liu, Guo, Shuang, Gong, Zhang, Yang, \& Zhang, 2005), 親和性に関連する社会行 動や社会認知における OT 神経系の重要性が示唆 されている (Donaldson \& Young, 2008)。また, 
茂木・永澤・菊水：イヌの社会性解明へ向けた発達行動学的アプローチ

Nagasawa, Kikusui, Onaka, \& Ohta (2008) の 研究では, OT とともに社会合図としての注視に着 目し，飼いイヌからの注視から始まる交流が多い飼 い主においては, 飼いイヌからの注視から始まる交 流の少ない飼い主と比較して, 飼いイヌとの交流後 に尿中 OTレベルがより上昇することを示した。 また，そのような飼いイヌからの注視が多い飼い主 においては, 自分の飼いイヌへの満足度がより高い こともアンケート調查によって明らかにしている。 つまりこの研究では, イヌからヒトへの注視がヒト の OT 神経系を刺激するとともに陽性の心的変化 も引き起こすことを示唆している。ヒトの赤ちゃん は社会合図として生得的に注視を用いると考元られ ており (Batki, Baron-Cohen, Wheelwright, Connellan, \& Ahluwalia, 2000 ; Farroni, Csibra, Simion, \& Johnson, 2002), 母親はそれを目的と 解釈して赤ちゃんに接近すると考えられているが (Meins, 1997)，イヌからヒトへの注視も同様の役 割を果たしているのかもしれない。我々はヒトーイ 又間の特異的な親和性は Bowlby（1969）が提唱し たヒトの母子間におけるアタッチメントと同義なも のとして，すなわち異種間のアタッチメントとして 捉えられるのではないかといら仮説を立てているが, 詳細は Nagasawa, Mogi, \& Kikusui (in press) を参照されたい。少なくともこれまでのイヌの比較 認知学的研究や神経科学的研究から, 他の動物では 同種の個体間で結ばれる関係性と類似したものがイ ヌにおいてはヒトとも結べるといらイヌの社会性の 特徵が浮き彫りにされつつあるといえよう。

\section{2. イヌの社会性発現における母子関係の重要性}

イヌの社会性を解明するためには Nagasawa, Kikusui, Onaka, et al. (2008) におけるアプロー チのような認知科学と神経科学の融合がますます重 要になってくるものと思われるが, イヌの社会性が 初生期環境によってどのように影響をうけるのかと いった発達行動学的な視点からのアプローチもまた 重要である。その重要性はカナダの Hebb やアメ リカの Roscoe B. Jackson 研究所などのグループ によって1950～60年代を中心に実施された多くの研 究によって示されている (Clarke, Heron, Fetherstonhaugh, Forgays, \& Hebb, 1951; Freedman, King, \& Elliot, 1961 ; Fuller, 1967 ; Scott \& Fuller, 1965 ; Scott, Stewart, \& De Ghett, 1974 ; Thompson \& Heron, 1954)。これ ら一連の研究では, イヌは発達期に人間社会と接触 することによって成長後にヒトへの恐怖反応が減少 し, 訓練性能が向上することを主に明らかにしてい る。また, 獣医学領域ではイヌが示すヒトに不都合
な非社会的行動が問題行動として分類されており， 人間社会の都市化とイヌの飼育様式の多様化を背景 にその発生件数が増加していることから近年注目を 集めているが，その発生要因を探索するための獣医 科病院などでの調査に捖いても初生期環境の重要性 が示されている。たとえば Appleby, Bradshaw, \& Casey（2002）は，子イヌが人間社会と接触す る時期と問題行動発生率との関連を調査しているが, 8 週齢までにヒトの家庭的な環境で飼育されなかっ たイヌは, 成長後にヒトを回避する行動や見知らぬ ヒトへの攻撃性が高いことを報告している。このよ うに1950～60年代を中心に実施された多くの研究や 問題行動の調査からは，イヌがヒトに対する社会性 を発達させるにはイヌがある時期までに人間社会と 接触することが重要であるといら点が強く示唆され ているが，我々はそれに加えて，さらにイヌの母子 関係にも着目していく必要があるのではないかと考 えている。イヌにおいてこのような視点からなされ た研究は少ないものの, Slabbert \& Rasa (1993) の研究では, 母イヌと巣を取り巻く環境からの 6 週 齢での子イヌの隔離は, 12週齢での隔離と比較して, 子イヌのその後の社会化や健康に悪影響を及ぼすこ とを報告している。また，アメリカの Serpell がオ ンラインのアンケート調查 (C-BARQ : Canine Behavioral Behavioral Assesment and Research Questionare) によって子イヌの入手年齢 と成長後の気質との関連性を解析したところ，6 週 齢までに母イヌから離され家庭に引き取られたイヌ は恐怖や接触刺激に対寸る反応性が高く, ストレス 反応性が増加して社会性が低下するという (Personal Communication)。つまりこれらことから，イヌ のヒトへの社会化のためには初生期に人間社会に接 触することが重要であるとしても，母子分離が早過 ぎるなど母子関係の粗悪化がある場合には逆効果的 な側面のあることが考えられる。近年, 觢歯類など の研究から様々な社会行動とその基盤となる OT 神経系などが，母子関係のよしあしを中心とした初 生期環境によってどのように影響をうけるかが明ら かになりつつあるが，そのような知見はイヌではほ とんど明らかにされていないのが現状である。イヌ の高度な社会技能や認知能力は恐怖反応や攻撃行動, $\mathrm{H}-\mathrm{P}-\mathrm{A}$ 軸とも密接に関連する可能性があることか らも, イヌにおいて発達段階のどの時期にどのよう な神経機構が母子関係の影響をうけて社会性の発達 に影響を与えるかを明らかにすることは，ヒトーイ 又間の親和性の謎を解くための一助となるのではな いだろらか。そこで本稿ではイヌの各発達過程にお ける母子関係が成長後の社会性に及ぼしうる影響と, その社会性変化の基盤となることが想定される神経 
機構を考察し，ヒトーイ又間における親和性解明に 向けての今後の発達行動学的アプローチについて展 望したい。

\section{3. イヌの各発達段階における社会性発現への影響}

Roscoe B. Jackson 研究所での研究などから (Markwell \& Thorne, 1987 ; Scott, Stewart, \& De Ghett, 1974), イヌの発達過程は一般的に胎生期, 生後 2 週齢までの新生子期, 生後 $2 \sim 3$ 週齢の移行 期, 生後 $3 \sim 12$ 週齢までの社会化期, 社会化期の終 了後から性成熟（6９ ケ月齢）までの若年期，性 成熟後の成熟期および 7 歳以降の老齢期に分けられ ると考えられている。本稿では主に母子関係を中心 として，離乳後の若年期までを概説したい。

\section{1 胎生期}

この時期に母親からの影響がイヌにもあるかどう かは今のところ全く不明であるが，ヒトにおいては 妊娠中にストレス/不安を経験した母親の子は認知 能力や感情表現に問題を抱えやすく（Van den Bergh, Mulder, Mennes, \& Glover, 2005), 統合 失調症のような精神疾患に罹患するリスクが高くな るという報告がある (Khashan, Abel, McNamee, Pedersen, Webb, Baker, Kenny, \& Mortensen, 2008)。これらの知見はストレス/不安を経験した 母親自身の育児行動に変化が生じることによる出生 後の影響も否定できないが, 縭歯類において妊娠期 にストレスをらけた母親の子を，ストレスを受けて いない母親に養育させる里子実験をおこならと，や はり成長後の情動性や社会行動が低下することが報 告されていることから (Lee, Brady, Shapiro, Dorsa, \& Koenig, 2007), おそらく胎生期の環境 が成長後の社会行動に影響を及ぼす可能性は高いで あろう。觢歯類およびヒトにおいて妊娠中にストレ ス/不安を経験した母親の子では，ストレスに対す る副腎皮質からの GC の過㮃な分泌が報告されて おり (Gutteling, de Weerth, \& Buitelaar, 2005 ; Koenig, Elmer, Shepard, Lee, Mayo, Joy, Hercher, \& Brady, 2005), 胎生期の影響が 社会性を低下させる神経基盤の一つとして H-P-A 軸の発達異常が示唆されている。妊娠中にストレス を受けた母親から生まれたラットでは脳内海馬にお ける GC 受容体の発現低下が示されており (Barbazanges, Piazza, Le Moal, \& Maccari, 1996), 海馬における GC のネガティブフィードバッ クが減弱化することによって GC が過剩に分泌さ れる機構の関与が考えられている。また, 妊娠中に ストレスを受けた母親から生まれたラットでは, 里 子実験においても社会行動の低下とともに視床下部
ニューロンでの OT 産生の低下や脳内扁桃体にお ける OT 受容体の発現増加が報告されており（Lee Brady, Shapiro, et al., 2007), 胎生期に母親がう けたストレスはOT 神経系の発達も阻害すること が示唆されている。妊娠中にストレス／不安状態に ある母親のどのような因子が胎生期の子に影響を与 えるのかという問題については, ストレスによって 母親から分泌される GC が子に直接的に影響して いるのではないかとする “GC 仮説”が提唱されて いるが (Barbazanges, Piazza, Le Moal, et al., 1996 ; Seckl \& Meaney, 2004), イヌも含めて多 くの動物の胎盤には GC を不活化する $11 \beta$-水酸化ス テロイド脱水素酵素が存在していることから (Sieber-Ruckstuhl, Meli, Boretti, Gonczi, Lutz, \& Reusch, 2007), 胎生期のストレス仲介因子に 関しては更なる研究が必要であろう。

\section{2 新生子期}

新生子は視覚と聴覚が未発達であり, 主に嗅覚情 報を頼りに母親に接近するが，まだ自分で排尿排便 はできない。新生子期は母親に完全に依存してのみ 生存できる時期といえる。觢歯類においては出生直 後からヒトがハンドリングをすることで成長後のス トレスに対する反応性が低下し，環境により順応し やすくなることからが示されており (Levine, 1967), この時期の触覚刺激が社会性の発達に重要 であることは古くから示唆されていた。カナダの Meaney らはこの時期のラットの母性行動に着目し, 出生直後から生後 1 週間までの時期に子への毛づく ろい行動を多く示す，いわゆる母性の高い母親に養 育された子では，毛づくろい行動の少ない母性の低 い母親に養育された子に比べて成長後の社会性が高 く, 新奇環境に対する恐怖反応や不安が低下寸るこ とや，ストレスに対する GC の分泌反応が低下寸 ることを明らかにしている(Caldji, Tannenbaum, Sharma, Francis, Plotsky, \& Meaney, 1998; Liu, Diorio, Tannenbaum, Caldji, Francis, Freedman, Sharma, Pearson, Plotsky, \& Meaney, 1997)。さらに，母性の高い母親に養育さ れた雌の子は, 成長後にやはり毛づくろい行動を多 く示す母性の高い母親となることも示されている

(Francis, Diorio, Liu, \& Meaney, 1999)。それ らに関与する神経機構の変化として, ストレスに対 する反応性低下には海馬に抢ける GC 受容体の発 現増加に起因する GC のネガティブフィードバッ クの増大が考えられており (Liu, Diorio, Tannenbaum, et al., 1997), この接触刺激による海馬 での GC 受容体発現増加にはセロトニンが必要で あることも示唆されている (Mitchell, Iny, \& 
茂木・永澤・菊水：イヌの社会性解明へ向けた発達行動学的アプローチ

Meaney, 1990 ; Smythe, Rowe, \& Meaney, 1994)。母性行動の促進に関しては母性行動発現に 重要だと考えられている脳内視床下部の視索前野に おける OT 受容体とエストロゲン受容体の発現増 加が関与すると考えられている (Champagne, Weaver, Diorio, Sharma, \& Meaney, 2003; Francis, Champagne, \& Meaney, 2000)。また, 興味深いことにこれらの効果は遺伝によるものでは なく, 里子実験によって母性の高い母親から産まれ た子を母性の低い母親に育てさせると，母性の高い 母親に養育されたときにみられる高い母性行動やス トレスへの低反応性は消失してしまう（Francis， Diorio, Liu, et al., 1999)。このようなエピジェネ ティックな変化には, この時期にうけた触覚刺激が $\mathrm{GC}$ 受容体遺伝子やエストロゲン受容体遺伝子にお けるDNAのメチル化を減少させることにより，そ れら受容体の成長後の発現が増加する機構が考えら れている (Champagne, Weaver, Diorio, Dymov, Szyf, \& Meaney, 2006 ; Weaver, Cervoni, Champagne, D’Alessio, Sharma, Seckl, Dymov, Szyf, \& Meaney, 2004)。イヌにおいては, この 時期の子イヌに対する母性行動を詳細に調い゙た研究 は残念ながら見当たらないが，Fox（1978）は出生 直後から 5 週間後まで様々な刺激に暴露されたイヌ では, 成長後に新奇環境下における大胆さと探究心 が向上することを報告しており，イヌにおいても新 生子期に打ける母親の育巟行動が $\mathrm{H}-\mathrm{P}-\mathrm{A}$ 軸や OT 神経系などの発達を変化させて成長後の社会性発現 に影響することは充分予想される。

イヌの新生子は出生直後から母乳を飲み始め, 生 活は主に睡眠と授乳に費やされるが，この時期はま だ血液一脳関門が未成熟であることから，母親の血 中から乳汁中に移行するような OT などの生理活 性ペプチドも新生子脳内に作用する可能性が考えら れる。ラットでは出生直後から14日間にわたって OT を皮下に投与すると, 成長後にストレスに対す る GC 分必反応が低下することが報告されている (Sohlstrom, Carlsson, \& Uvnas-Moberg, 2000)。 また, 生物学的に一夫一婦制をとるプレーリーハ夕 ネズミを用いた Carter らによる一連の研究によれば, 出生直後の新生子に OT や OT アンタゴニストを 腹腔内に投与して OT 暴露量を操作すると, OT 暴 露が多いほど成長後にパートナーの選好性が高くな ることや，ストレスに対する GC 分泌の反応性が 変化することなどが報告されており (Bales \& Carter, 2003 ; Kramer, Cushing, \& Carter, 2003), 授乳によって母親から子へ移行する OT が 脳内に作用し, OT 神経系自身や OT 神経系同様に 社会性発現への重要性が示唆されているバソプレッ
シン神経系の発達に影響を及ぼすのでないかという 興味深い仮説が提唱されている (Carter, 2003)。 ヒトでは子供に示す愛着行動が多い母親ほど血中 OTレベルが高いといった報告があることから

(Feldman, Weller, Zagoory-Sharon, et al., 2007)，母性の高い母親に養育された子ほど乳汁を 介してより多くの OT に暴露されることが推測さ れるが, このような生理機構も母性の高い母親に養 育された子の社会性が高くなる一因かもしれない。

\section{3 移行期}

移行期とは文字通りに母親に完全に依存した状態 から多少独立した状態へと変化する時期で, 眼瞼が 開いて光や動く刺激に反応するようになり, 外耳道 が開いて大きな音に反応し始めるくらいまでの一週 間程度の期間である。運動能力も向上してぎこちな いが立ち上がり歩行が可能となる。野生のオオカミ では暗闇の巣穴からはじめて外界に出てくる時期に 相当する (Frank \& Frank, 1982)。

\section{4 社会化期}

この時期に社会的に遭遇したヒトなどの他の動物 種に対して, イヌの成長後の行動反応が影響をうけ ることは1950〜60年代を中心によく調べられており， 主にヒトへの恐怖反応と訓練性能を指標とする社会 性が初生期環境によっていかに影響をうけるかが明 らかにされている。代表的な研究として Freedman, King, \& Elliot (1961) は, ヒトとの 社会的接触を図れる時期を生後 2 週歯, 3 週齢, 5 週齢， 7 週齢，9週齢のそれぞれ 1 週間のみにした 群と生後14週齢まで全くヒトから隔離する群をつく り，14週齢にすべてのイヌのじっとしている実験者 への反応や引き綱をつけて歩かせたりしたときなど の訓練への反応を評価した。その結果, 生後 5 週齢 から 9 週齢の間に 1 週間だけヒトとの社会的接触を 図ったイヌではヒトへの恐怖反応を示さずに訓練し やすいが，生後14週齢までヒトとの社会的接触がな いとその後何週間も優しく扱ったりしても恐怖心が 認められ扱いにくいことを報告している。また，こ のようなヒトへの社会化には頻繁な接触や長時間の 接触泌要がなく, 社会化期間中に少なくとも週に 20分のヒトとの接触が 2 回あれば可能になるという

(Fuller, 1967)。このようなことから，社会化期 はローレンツによって提唱された鳥類の子の刷り込 み現象を説明するための概念である “臨界期” と同 様に, 特殊な選好性を獲得するごく限られた発達期 間だと認識されてきたが，現在では他の時期よりも 特殊な反応や選好性を獲得しやすい “感受期”とし て捉えられている。Scott \& Fuller（1965）がさ 
まざまな年齢の子イヌの実験者への反応を行動学的 に観察したところ, 生後 $3 \sim 5$ 週齢頃は見慣れぬヒ トでも近づいて社会的接触を図ろらとする行動が急 速に強まるが, その後この傾向は減退し，12週歯を 過ぎると傾向として次第に見慣れぬヒトや初めて経 験する場所に対して不安や恐怖反応がみられたこと から, 社会化期は生後 $3 \sim 12$ 週齢の間であり, “感 受期” の頂点は 6 〜 週齢であると結論づけている。 Fox \& Stelzner (1966) がヒトとの接触と同時に 子イヌに電気ショックを与える嫌悪条件づけを 5 週 歯令， 8 週齢，12週齢に行った実験でも， 5 週齢と 12 週齢とは異なり，8週齢に嫌悪条件づけした場合に おいてのみ長期にわたる嫌悪効果が観察されている。 子イヌを新奇環境下におき，心拍と苦悩に満ちた鳴 き声を発する度合を測定した実験においても，その ピークは 6 〜 週齢頃であるという (Elliot \& Scott, 1961)。

生後 6 ～週におけるイヌとヒトとの社会的接触 が成長後のヒトーイヌ間の親和性に大きく影響する であろらことは容易に想像されるが, 生後 6 〜 週 齢のイヌにおいてヒトへの選好や嫌悪はどのように 獲得されるのだろらか? イヌにおけるその機構は全 く明らかにされていないが, Moriceau \& Sullivan（2006）が舾歯類において見出した現象が それを探る一つの手がかりとなるかもしれない。生 後 8 日歯令, 12〜 15 日歯令, 21〜23日歯のラットの子に ペパーミントの匂いを対提示しながら電気ショック を与える嫌悪条件づけを行った実験であるが，まず 離乳直前の生後21〜23日齢の子ラットでは匂いの嫌 悪学習が成立するのに対して, 生後 8 日歯令の子ラッ トでは嫌悪学習が成立せず，逆にその匂いを選好す るようになる。この嫌悪学習が成立しない原因とし ては, 生後 8 日歯は H-P-A 軸が未発達であるため に電気ショック負荷によっても GC 分泌が促進さ れない $\mathrm{H}-\mathrm{P}-\mathrm{A}$ 軸の不応期であるとともに, 嫌悪学 習に重要だと考えられている脳内扁桃体の機能も未 発達であるためであることが明らかとなっている。 嫌悪条件づけによって逆に匂いへの選好性を生み出 してしまら機構の詳細は明らかにされていないが, この時期は延髄青斑核から嗅球へのノルアドレナリ ン分泌が成長後よりも過剰であることが明らかにさ れており,その一因として嗅覚機能が成長後と異なっ ていることが考えられている (Moriceau\& Sullivan, 2005)。イヌにおける H-P-A 軸の不応期 やこの時期の嗅覚機能などは未だ調べられていない ために推測の域を出ないが, 生後 $3 \sim 5$ 週齢頃の子 イヌは見慣れぬヒトでも近づいて社会的接触を図ろ うとするといった Scott \& Fuller（1965）による 観察や，子イヌの電気ショック実験では 5 週齢で嫌
悪条件づけが成立しなかったことなどを考慮すると

(Fox \& Stelzner, 1966)，おそらくイヌも生後 5 週齢程度まではラットの生後 8 日齢と同様の生理状 態であることが推測される。そして, Moriceau \& Sullivan（2006）によって明らかとなった最も興味 深い現象は，授乳は少なくなるが離乳には至らない 生後12〜15日齢のラットでみられる。この時期は扁 桃体が機能し始めるとともに H-P-A 軸が発達して 電気ショックによる $\mathrm{GC}$ 分泌反応も認められ, 生 後21〜23日齢のラット同様に嫌悪条件づけが成立す るが，これには嫌悪条件づけを行ら際に母親が不在 であるという条件が必要なことが明らかとなったの である。つまり，この時期に母親が存在している状 態（母親は麻酔下にある）で嫌悪条件づけをした場 合, 電気ショックによる GC 分泌反応が抑制され る結果として嫌悪条件づけが成立しないのである。 このように他個体の存在によって H-P-A 軸などの ストレス反応が減弱する現象は“Social buffering”として知られており，その仲介因子や メカニズムには不明な点が多いものの，社会的な動 物ではこのような母子関係以外でも広く認められる 現象である (Kikusui, Winslow, \& Mori, 2006)。 イヌにおいても “感受期” の頂点だと考えられてい る 6 〜 週齢頃は, 授乳は少ないものの完全には離 乳する前の時期という点で生後 $12 \sim 15$ 日齢のラット とほぼ同時期であり，母親の在不在で刺激に対する $\mathrm{GC}$ 分泌反応が変化して嫌悪学習の成否が決まる生 理状態にあるのかもしれない。もしこのような生理 的背景が存在すれば，この時期のヒトとの社会的接 触が成長後のヒトへの社会化に重要であることを明 らかにした一連の研究と, 逆に 6 週齢までに母犬か ら離されたイヌは社会性が低下することを示した研 究やアンケート調查の両方を説明することが可能で ある。今後の研究を待たなくてはならないが, イヌ における社会化期とは，人間社会と接触することで ヒトへの社会化に重要な時期であるとともに，母子 関係が安定していない状況で人間社会に接触した場 合には逆にヒトへの嫌悪も獲得しやすい時期といえ るかもしれない。

イヌでは社会化期における早期の母子分離が成長 後の社会性に影響を及ぼすかどうかを実験的に実証 した研究は少ないのが現状であるが，㱖歯類におい ては授乳後期に通常よりも早期に離乳させると，成 長後の社会行動が影響をらけることが多くの実験か ら示されている。たとえば，通常生後21日齢で離乳 するマウスを 1 週間早い14日齢で離乳すると，成長 後に不安行動や攻撃行動が増加するとともにストレ スに対する $\mathrm{H}-\mathrm{P}-\mathrm{A}$ 軸の反応性も増大することが明 らかとなっている (Kikusui, Takeuchi, \& Mori, 
茂木・永澤・菊水：イヌの社会性解明へ向けた発達行動学的アプローチ

2004 ; Kikusui, Nakamura, Kakuma, \& Mori, 2006 ; Nakamura, Kikusui, Takeuchi, \& Mori, 2008)。このような早期離乳マウスにおいては，海 馬における GC 受容体発現の変化に加えて (Kikusui, Nakamura, Kakuma, et al., 2006)，やはり海馬 におけるセロトニンレセプターの発現低下といった セロトニン神経系の発達阻害が認められている

(Nakamura, Kikusui, Takeuchi, et al., 2008)。 授乳後期のマウス海馬におけるセロトニンと GC 受容体の機能的関連は不明であるが，前述した新生 子期のラット海馬で示唆されているように (Mitchell, Iny, \& Meaney, 1990 ; Smythe, Rowe, \& Meaney, 1994), 授乳後期のマウス海馬における $\mathrm{GC}$ 受容体発現もセロトニンによって影響を受ける のかもしれない。マウスではセロトニン神経系は授 乳後期から発達を開始するが, 遺伝子工学により脳 内のセロトニン受容体を時期特異的に授乳期間のみ 欠損させたマウスでは成長後に不安行動が増加する ことも示されており (Gross, Zhuang, Stark, Ramboz, Oosting, Kirby, Santarelli, Beck, \& Hen, 2002), 授乳期のセロトニン神経系の発達は 成長後の不安行動発現に大きく影響することが考え られる (Gross \& Hen, 2004)。さらに, セロトニ ンの生成や脳内のセロトニン受容体を欠損させたマ ウスでは, 嫌悪条件づけ後の嫌悪刺激に対する反応 が増加するとともに嫌悪記憶が消去されづらくなる ことも報告されている (Dai, Han, Tian, Cao, Xiu, Song, Huang, Xu, Ding, \& Xu, 2008; Klemenhagen, Gordon, David, Hen, \& Gross, 2006)。イヌにおけるセロトニン神経系の発達過程 は明らかにされていないが，支配性攻撃行動として 分類されたイヌの脳内変化を調べた研究ではセロト ニン神経系に異常のあることが多数報告されている

(Badino, Odore, Osella, Bergamasco, Francone, Girardi, \& Re, 2004 ; Peremans, Audenaert, Coopman, Blanckaert, Jacobs, Otte, Verschooten, Van Bree, Van Heeringen, Mertens, Slegers, \& Dierckx, 2003 ; Reisner, Mann, Stanley, Huang, \& Houpt, 1996)。これ らのことから, Slabbert \& Rasaの研究 (1993) や Serpell のアンケート調査 (Personal Communication）で示されたような早期に母子分離された イヌでみられる社会性低下の一因として, セロトニ ン神経系の発達阻害が関与することは充分に考えら れる。

\section{5 若年期}

この時期は運動能力が飛躍的に向上し, 性腺の発 達に伴ってそれぞれの性に従った社会行動が発達す
る。また，ヒトーイヌ間の親和性形成に影響を与え る行動として, テリトリー意識が発達して汱えるな ぞの攻撃行動がみられ始める。オオカミにおいては 生後 4〜6 个月齢頃に巣穴から離れてらろつき始め るが (Mech, 1970)，この時期は見知らぬ侵入者に 対してあからさまに敵意を示す行動をとり始めるこ となどから，オオカミには新奇な刺激や恐怖を引き 起こす刺激に対して強い感受性を示寸第 2 の感受期 が存在するという (Fentress, 1967 ; Fox, 1971 ; Mech，1970)。しかし，イヌにおいてもこのような 第 2 の感受期が存在するのかどうかを科学的に解析 した研究は残念ながらほとんどなく, 今後の研究が 待たれる。

\section{4. 今後の行動発達学的アプローチの展望}

多くの哺乳動物の発達過程において, おそらく胎 生期も含めた母子関係を中心とする初生期環境が成 長後の社会性発現に重大な影響を及ぼすことは明ら かであり，母子関係が良好であれば子の社会性が高 くなり，母子関係が阻害されると子の社会性は低く なるといら関係性は科学的にも証明されてきている。 しかし，イヌにおいてそのような視点からなされた 研究がほとんどないことが本稿から改めて浮き彫り となったのではないだろうか。イヌにおいても新生 子期における様々な刺激が成長後の社会性を高める といった効果はこれまでも認められていることから， まずは新生子期に母イヌが示す授乳行動や毛づくろ い行動などの母性行動のよしあしと子イヌの成長後 のヒトへの親和性や攻撃性などとの関連を,

$\mathrm{H}-\mathrm{P}-\mathrm{A}$ 軸や OT 神経系の発達度合などとともに解 析してゆくことで，イヌにおいて母子関係が社会性 を変化させる機構の一端が明らかとなることが期待 される。

また，これまで多くの研究から示唆されてきた社 会化期，特に “感受期” の頂点だと考えられている $6 \sim 8$ 週齢頃にどのような神経科学的変化が起きて いるかを解明することもヒトーイ又間でみられる特 異的な親和性の謎を解くための大きな課題である。

Moriceau \& Sullivan（2006）が艂歯類において 明らかにしたような現象がイヌにも存在するかどう かを検証することが重要だと考えているが，まずは 社会化期の子イヌにおける $\mathrm{H}-\mathrm{P}-\mathrm{A}$ 軸の不応期がい つ頃までなのか, さらに不応期の終了後に母親によ る “Social buffering” がイヌにも認められるのか どうかを，ストレス負荷時の GC 分泌反応の解析 などによって明らかしていく必要があるであろう。

イヌの有する高度な社会技能の獲得は $\mathrm{H}-\mathrm{P}-\mathrm{A}$ 軸 の活性低下や恐怖反応の低下に関連する可能性が示 唆されるが, 縭歯類では新生子期の良好な母子関係 
によって H-P-A 軸の活性や恐怖反応が低下し，逆 に早期の母子分離など社会化期の母子関係の阻害に よって $\mathrm{H}-\mathrm{P}-\mathrm{A}$ 軸の活性や恐怖反応が上昇すること が明らかになっていることから，イヌの各発達段階 における母子関係と成長後の社会技能との関連性も 興味深い。Nagasawa, Kikusui, Onaka, et al.

(2008) の研究では, 飼いイヌは飼い主への注視が 多いイヌと少ないイヌとに分けられることを示して いるが，ヒトでは OTの経鼻投与によって他人の 目の周辺をよく見るようになるという報告があるこ とから (Guastella, Mitchell, \& Dadds, 2008), 注視は OT 神経系によって影響をうけていること が考えられる。觢歯類では母子関係のよしあしが OT 神経系の発達を変化させる可能性が示されてい るが，このようなことがイヌでも起きているとすれ ば, Nagasawa, Kikusui, Onaka, et al. (2008) の研究でみられたイヌによるヒトへの注視の多さの 違いは, 研究に用いたイ又の発達期における母子関 係に起因する可能性も考えられる。今後のイヌにお ける認知学的研究に打いても, 研究に使用するイヌ の発達期における母子関係に注意を払う必要がある かもしれない。

イヌにおける発達行動学的研究の成否は, まずイ 又の母子関係や子イヌの発達段階を一定の環境下に おいてどれだけ多くの例数を観察できるかにかかっ ているが，現在我々はその条件をクリアできる日本 盲導犬協会の繁殖・育成施設に拈いて共同研究を進 めているところである。今後, イヌの社会性の解明 に発達行動学的なアプローチから少しでも貢献でき れば幸いである。

\section{引用 文 献}

Appleby, D. L., Bradshaw, J. W., \& Casey, R. A. 2002 Relationship between aggressive and avoidance behaviour by dogs and their experience in the first six months of life. The Veterinary Record, 150, 434438.

Badino, P., Odore, R., Osella, M. C., Bergamasco, L., Francone, P., Girardi, C., \& Re, G. 2004 Modifications of serotonergic and adrenergic receptor concentrations in the brain of aggressive canis familiaris. Comparative Biochemistry and Physiology. Part A, Molecular \& Integrative Physiology, 139, 343-350.

Bales, K. L., \& Carter, C. S. 2003 Developmental exposure to oxytocin facilitates partner preferences in male prairie voles (microtus ochrogaster). Behavioral Neuroscience, 117, 854-859.

Barbazanges, A., Piazza, P. V., Le Moal, M., \& Maccari, S. 1996 Maternal glucocorticoid secretion mediates long-term effects of prenatal stress. The Journal of Neuroscience, 16, 3943-3949.

Batki, A., Baron-Cohen, S., Wheelwright, S., Connellan, J., \& Ahluwalia, J. 2000 Is there an innate gaze module? evidence from human neonates. Infant Behavior and Development, 23, 223-229.

Bowlby, J. 1969 Attachment and loss: Vol. I. attachment. New York: Basic Books.

Caldji, C., Tannenbaum, B., Sharma, S., Francis, D., Plotsky, P. M., \& Meaney, M. J. 1998 Maternal care during infancy regulates the development of neural systems mediating the expression of fearfulness in the rat. Proceedings of the National Academy of Sciences of the United States of America, 95, 5335-5340.

Carter, C. S. 2003 Developmental consequences of oxytocin. Physiology \& Behavior, 79, 383-397.

Champagne, F. A., Weaver, I. C., Diorio, J., Dymov, S., Szyf, M., \& Meaney, M. J. 2006 Maternal care associated with methylation of the estrogen receptor-alphalb promoter and estrogen receptor-alpha expression in the medial preoptic area of female offspring. Endocrinology, 147, 2909-2915.

Champagne, F. A., Weaver, I. C., Diorio, J., Sharma, S., \& Meaney, M. J. 2003 Natural variations in maternal care are associated with estrogen receptor alpha expression and estrogen sensitivity in the medial preoptic area. Endocrinology, 144, 47204724

Clarke, R. S., Heron, W., Fetherstonhaugh, M. L., Forgays, D. G., \& Hebb, D. O. 1951 Individual differences in dogs: Preliminary report on the effects of early experience. Canadian Journal of Psychology, 5, 150-156.

Dai, J. X., Han, H. L., Tian, M., Cao, J., Xiu, J. B., Song, N. N., Huang, Y., Xu, T. L., 
Ding, Y. Q., \& Xu, L. 2008 Enhanced contextual fear memory in central serotonin-deficient mice. Proceedings of the National Academy of Sciences of the United States of America, 105, 1198111986.

Donaldson, Z. R., \& Young, L. J. 2008 Oxytocin, vasopressin, and the neurogenetics of sociality. Science, 322, 900-904.

Elliot, O., \& Scott, J. P. 1961 The development of emotional distress reactions to separation, in puppies. The Journal of Genetic Psychology, 99, 3-22.

Farroni, T., Csibra, G., Simion, F., \& Johnson, M. H. 2002 Eye contact detection in humans from birth. Proceedings of the National Academy of Sciences of the United States of America, 99, 9602-9605.

Feldman, R., Weller, A., Zagoory-Sharon, O., \& Levine, A. 2007 Evidence for a neuroendocrinological foundation of human affiliation: Plasma oxytocin levels across pregnancy and the postpartum period predict mother-infant bonding. Psychological Science, 18, 965-970.

Fentress, J. C. 1967 Observations on the behavioral development of a hand-reared male timber wolf. American Zoologist, 7 , 339-351.

Ferguson, J. N., Young, L. J., Hearn, E. F., Matzuk, M. M., Insel, T. R., \& Winslow, J. T. 2000 Social amnesia in mice lacking the oxytocin gene. Nature Genetics, 25, 284-288.

Fox, M. W. 1971 Behaviour of wolves, dogs, and related canids. New York: Harper \& Row.

Fox, M. W. 1978 The dog: Its domestication and behavior. New York: Garland STPM Press.

Fox, M. W., \& Stelzner, D. 1966 Approach/ withdrawal variables in the development of social behaviour in the dog. Animal Behaviour, 14, 362-366.

Francis, D., Diorio, J., Liu, D., \& Meaney, M. J. 1999 Nongenomic transmission across generations of maternal behavior and stress responses in the rat. Science, 286, 1155-1158.
Francis, D. D., Champagne, F. C., \& Meaney, M. J. 2000 Variations in maternal behaviour are associated with differences in oxytocin receptor levels in the rat. Journal of Neuroendocrinology, 12, 11451148.

Frank, H., \& Frank, M. G. 1982 On the effects of domestication on canine social development and behavior. Applied Animal Ethology, 8, 507-525.

Freedman, D. G., King, J. A., \& Elliot, O. 1961 Critical period in the social development of dogs. Science, 133, 10161017.

Fuller, J. L. 1967 Experiential deprivation and later behavior. Science, 158, 1645-1652.

Green, L., Fein, D., Modahl, C., Feinstein, C., Waterhouse, L., \& Morris, M. 2001 Oxytocin and autistic disorder: Alterations in peptide forms. Biological Psychiatry, 50, 609-613.

Gross, C., \& Hen, R. 2004 The developmental origins of anxiety. Nature Reviews Neuroscience, 5, 545-552.

Gross, C., Zhuang, X., Stark, K., Ramboz, S., Oosting, R., Kirby, L., Santarelli, L., Beck, S., \& Hen, R. 2002 Serotonin1A receptor acts during development to establish normal anxiety-like behaviour in the adult. Nature, 416, 396-400.

Guastella, A. J., Mitchell, P. B., \& Dadds, M. R. 2008 Oxytocin increases gaze to the eye region of human faces. Biological Psychiatry, 63, 3-5.

Gutteling, B. M., de Weerth, C., \& Buitelaar, J. K. 2005 Prenatal stress and children's cortisol reaction to the first day of school. Psychoneuroendocrinology, 30, 541-549.

Haller, J., Makara, G. B., Barna, I., Kovacs, K., Nagy, J., \& Vecsernyes, M. 1996 Compression of the pituitary stalk elicits chronic increases in CSF vasopressin, oxytocin as well as in social investigation and aggressiveness. Journal of Neuroendocrinology, 8, 361-365.

Hare, B., Brown, M., Williamson, C., \& Tomasello, M. 2002 The domestication of social cognition in dogs. Science, 298, 
1634-1636.

Hare, B., Plyusnina, I., Ignacio, N., Schepina, O., Stepika, A., Wrangham, R., \& Trut, L. 2005 Social cognitive evolution in captive foxes is a correlated by-product of experimental domestication. Current Biology, 15, 226-230.

Hare, B., \& Tomasello, M. 2005 Human-like social skills in dogs? Trends in Cognitive Sciences, 9, 439-444.

Khashan, A. S., Abel, K. M., McNamee, R., Pedersen, M. G., Webb, R. T., Baker, P. N., Kenny, L. C., \& Mortensen, P., B. 2008 Higher risk of offspring schizophrenia following antenatal maternal exposure to severe adverse life events. Archives of General Psychiatry, 65, 146-152.

Kikusui, T., Nakamura, K., Kakuma, Y., \& Mori, Y. 2006 Early weaning augments neuroendocrine stress responses in mice. Behavioural Brain Research, 175, 96-103.

Kikusui, T., Takeuchi, Y., \& Mori, Y. 2004 Early weaning induces anxiety and aggression in adult mice. Physiology \& Behavior, 81, 37-42.

Kikusui, T., Winslow, J. T., \& Mori, Y. 2006 Social buffering: Relief from stress and anxiety. Philosophical Transactions of the Royal Society of London.Series B, Biological Sciences, 361, 2215-2228.

Klemenhagen, K. C., Gordon, J. A., David, D. J., Hen, R., \& Gross, C. T. 2006 Increased fear response to contextual cues in mice lacking the 5-HT1A receptor. Neuropsychopharmacology 31, 101-111.

Koenig, J. I., Elmer, G. I., Shepard, P. D., Lee, P. R., Mayo, C., Joy, B., Hercher, E., \& Brady, D. L. 2005 Prenatal exposure to a repeated variable stress paradigm elicits behavioral and neuroendocrinological changes in the adult offspring: Potential relevance to schizophrenia. Behavioural Brain Research, 156, 251-261.

Kramer, K. M., Cushing, B. S., \& Carter, C. S. 2003 Developmental effects of oxytocin on stress response: Single versus repeated exposure. Physiology \& Behavior, 79, 775-782.

Lee, P. R., Brady, D. L., Shapiro, R. A.,
Dorsa, D. M., \& Koenig, J. I. 2007 Prenatal stress generates deficits in rat social behavior: Reversal by oxytocin. Brain Research, 1156, 152-167.

Levine, S. 1967 Maternal and environmental influences on the adrenocortical response to stress in weanling rats. Science, 156 , 258-260.

Liu, D., Diorio, J., Tannenbaum, B., Caldji, C., Francis, D., Freedman, A., Sharma, S., Pearson, D., Plotsky, P. M., \& Meaney, M. J. 1997 Maternal care, hippocampal glucocorticoid receptors, and hypothalamic-pituitary-adrenal responses to stress. Science, 277, 1659-1662.

Markwell, P., \& Thorne, C. 1987 Early behavioural development of dogs. Journal of Small Animal Practice, 28, 984-991.

Mech, L. D. 1970 The wolf: The ecology and behavior of an endangered species. New York: Natural History Press.

Meins, E. 1997 Security of attachment and the social development of cognition. essays in developmental psychology. Philadelphia: Psychology Press.

Miklósi, A., Kubinyi, E., Topál, J., Gácsi, M., Virányi, Z., \& Csányi, V. 2003 A simple reason for a big difference: Wolves do not look back at humans, but dogs do. Current Biology, 13, 763-766.

Mitchell, J. B., Iny, L. J. \& Meaney, M. J. 1990 The role of serotonin in the development and environmental regulation of type II corticosteroid receptor binding in rat hippocampus. Developmental Brain Research, 55, 231-235.

Moriceau, S., \& Sullivan, R. M. 2005 Neurobiology of infant attachment. Developmental Psychobiology, 47, 230-242.

Moriceau, S., \& Sullivan, R. M. 2006 Maternal presence serves as a switch between learning fear and attraction in infancy. Nature Neuroscience, 9, 1004-1006.

Nagasawa, M., Kikusui, T., Onaka, T., \& Ohta, M. 2008 Dog's gaze at its owner increases owner's urinary oxytocin during social interaction. Hormones and Behavior, 55, 431-441.

Nagasawa, M., Mogi, K., \& Kikusui, T. 
茂木・永澤・菊水：イヌの社会性解明へ向けた発達行動学的アプローチ

Attachment between humans and dogs. Japanease Psychological Research, in press.

Nakamura, K., Kikusui, T., Takeuchi, Y., \& Mori, Y. 2008 Changes in social instigation- and food restriction-induced aggressive behaviors and hippocampal 5HT1B mRNA receptor expression in male mice from early weaning. Behavioural Brain Research, 187, 442-448.

Odendaal, J. S., \& Meintjes, R. A. 2003 Neurophysiological correlates of affiliative behaviour between humans and dogs. Veterinary Journal, 165, 296-301.

Oskina, I. N. 1996 Analysis of the functional state of the pituitary-adrenal axis during postnatal development of domesticated silver foxes (vulpes vulpes). Scientifur, 20, 159-167.

Pedersen, C. A., Caldwell, J. D., Drago, F., Noonan, L. R., Peterson, G., Hood, L. E., \& Prange, A. J. Jr. 1988 Grooming behavioral effects of oxytocin. pharmacology, ontogeny, and comparisons with other nonapeptides. Annals of the New York Academy of Sciences, 525, 245-256.

Peremans, K., Audenaert, K., Coopman, F., Blanckaert, P., Jacobs, F., Otte, A., Verschooten, F., Van Bree, H., Van Heeringen, K., Mertens, J., Slegers, G., \& Dierckx, R. 2003 Estimates of regional cerebral blood flow and 5-HT2A receptor density in impulsive, aggressive dogs with 99mTc-ECD and 123I-5-I-R91150. European Journal of Nuclear Medicine and Molecular Imaging, 30, 1538-1546.

Popova, N. K., Voitenko, N. N., Kulikov, A. V., \& Avgustinovich, D. F. 1991 Evidence for the involvement of central serotonin in mechanism of domestication of silver foxes. Pharmacology, Biochemistry, and Behavior, 40, 751-756.

Reisner, I. R., Mann, J. J., Stanley, M., Huang, Y. Y., \& Houpt, K. A. 1996 Comparison of cerebrospinal fluid monoamine metabolite levels in dominantaggressive and non-aggressive dogs. Brain Research, 714, 57-64.

Scott, J. P., \& Fuller, J. L. 1965 Genetics and the social behavior of the dog. Chicago: University of Chicago Press.

Scott, J. P., Stewart, J. M., \& De Ghett, V. J. 1974 Critical periods in the organization of systems. Developmental Psychobiology, 7, 489-513.

Seckl, J. R., \& Meaney, M. J. 2004 Glucocorticoid programming. Annals of the New York Academy of Sciences, 1032, 63-84.

Serpell, J. 1995 The domestic dog: Its evolution, behaviour, and interactions with people. Cambridge: Cambridge University Press.

Sieber-Ruckstuhl, N. S., Meli, M. L., Boretti, F. S., Gonczi, E., Lutz, H., \& Reusch, C. E. 2007 Quantitative real-time PCR for the measurement of 11beta-HSD1 and 11beta-HSD2 mRNA levels in tissues of healthy dogs. Hormone and Metabolic Research. Hormon-Und Stoffwechselforschung. Hormones Et Metabolisme, 39, 548554.

Slabbert, J. M., \& Rasa, O. A. 1993 The effect of early separation from the mother on pups in bonding to humans and pup health. Journal of the South African Veterinary Association, 64, 4-8.

Smythe, J. W., Rowe, W., \& Meaney, M. J. 1994 Neonatal handling alters serotonin turnover and serotonin type 2 receptor density in selected brain regions. Developmental Brain Research, 80, 183-189.

Sohlstrom, A., Carlsson, C., \& Uvnas-Moberg, K. 2000 Effects of oxytocin treatment in early life on body weight and corticosterone in adult offspring from ad libitumfed and food-restricted rats. Biology of the Neonate, 78, 33-40.

Thompson, W. R., \& Heron, W. 1954 The effects of restricting early experience on the problem-solving capacity of dogs. Canadian Journal of Psychology, 8, 1731.

Topál, J., Gácsi, M., Miklósi, Á, Virányi, Z., Kubinyi, E., \& Csányi, V. 2005 Attachment to humans: A comparative study on hand-reared wolves and differently socialized dog puppies. Animal Behaviour, 70, $1367-1375$. 
Topál, J., Miklósi, A., Csányi, V., \& Dóka, A. 1998 Attachment behavior in dogs (canis familiaris): A new application of ainsworth's (1969) strange situation test. Journal of Comparative Psychology, 112, 219-229.

Udell, M. A. R., Dorey, N. R., \& Wynne, C. D. L. 2008 Wolves outperform dogs in following human social cues. Animal Behaviour, 766, 1767-1773.

Van den Bergh, B. R., Mulder, E. J., Mennes, M., \& Glover, V. 2005 Antenatal maternal anxiety and stress and the neurobehavioural development of the fetus and child: Links and possible mechanisms. A review. Neuroscience and Biobehavioral Reviews, 29, 237-258.

Virányi, Z., Gácsi, M., Kubinyi, E., Topál, J., Belényi, B., Ujfalussy, D., \& Miklósi, A. 2008 Comprehension of human pointing gestures in young human-reared wolves (canis lupus) and dogs (canis familiaris). Animal Cognition, 11, 373-387.

Weaver, I. C., Cervoni, N., Champagne, F. A., D’Alessio, A. C., Sharma, S., Seckl, J. R., Dymov, S., Szyf, M., \& Meaney, M. J.
2004 Epigenetic programming by maternal behavior. Nature Neuroscience, 7, 847854.

Winslow, J. T., \& Insel, T. R. 2002 The social deficits of the oxytocin knockout mouse. Neuropeptides, 36, 221-229.

Witt, D. M., Winslow, J. T., \& Insel, T. R. 1992 Enhanced social interactions in rats following chronic, centrally infused oxytocin. Pharmacology, Biochemistry, and Behavior, 43, 855-861.

Wu, S., Jia, M., Ruan, Y., Liu, J., Guo, Y., Shuang, M., Gong, X., Zhang, Y., Yang, X., \& Zhang, D. 2005 Positive association of the oxytocin receptor gene (OXTR) with autism in the chinese han population. Biological Psychiatry, 58, 74-77.

Young, L. J., Lim, M. M., Gingrich, B., \& Insel, T. R. 2001 Cellular mechanisms of social attachment. Hormones and Behavior, 40, 133-138.

Young, L. J., \& Wang, Z. 2004 The neurobiology of pair bonding. Nature Neuroscience, 7, 1048-1054.

（2009. 1. 31 受稿，2009. 3.28 受理） 